\title{
Probucol Protects Endothelial Progenitor Cells Against Oxidized Low-Density Lipoprotein via Suppression of Reactive Oxygen Species Formation In Vivo
}

\author{
Qingbin Zhang ${ }^{\mathrm{a}}$ Liming Chen ${ }^{\mathrm{a}}$ Zhihua $\mathrm{Si}^{\mathrm{d}} \mathrm{Haoran} \mathrm{Bu}^{\mathrm{f}}$ \\ Chandrakala A. Narasimhulue Xueling Song ${ }^{\mathrm{e}}$ Ming-Yu Cuic Hang Liu ${ }^{\mathrm{a}}$ \\ Tiewei Lu ${ }^{b} \quad$ Guanglong He ${ }^{b}$ Sampath Parthasarathy ${ }^{e}$ Lianqun Cuia \\ Zhenguo Liubr, Yuqi Cui ${ }^{\mathrm{a}, \mathrm{b}}$
}

aDepartment of Cardiology, Shandong Provincial Hospital affiliated to Shandong University, Jinan,

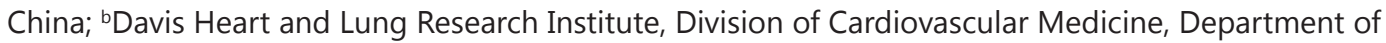
Internal Medicine, The Ohio State University Wexner Medical Center, Columbus, OH, USA; 'Department of Pediatric Surgery, Shandong Provincial Hospital, Shandong University, Jinan, China; dDepartment of neurology, Qianfoshan Hospital, Shandong University, Jinan, China; 'Burnett School of Biomedical Sciences, University of Central Florida College of Medicine, Orlando, FL, USA; ' ${ }^{\mathrm{D}}$ eppartment of Gastroenterology, Shandong Provincial Hospital, Shandong University, Jinan, , China; ${ }^{9}$ Clinical Skills Training Center, Shandong Provincial Hospital, Shandong University, Jinan, China

\section{Key Word}

Probucol • Endothelial progenitor cells • Oxidized low-density lipoprotein • Reactive oxygen species

\begin{abstract}
Background/Aims: Oxidized low-density lipoprotein (ox-LDL) is a major component of hyperlipidemia and contributes to atherosclerosis. Endothelial progenitor cells (EPCs) play an important role in preventing atherosclerosis and notably decreased in hyperlipidemia. Ox-LDL and ox-LDL-related reactive oxygen species (ROS) have deleterious effects on EPCs. Probucol as an antioxidant and anti-inflammatory drug reduces ROS production. The present study was to determine if probucol could protect EPCs from ox-LDL in vivo and to investigate the potential mechanisms. Methods: ox-LDL was injected into male C57BL/6 mice for 3 days with or without probucol treatment with PBS as control. Bone marrow (BM) fluid, serum, circulating mononuclear cells (MNCs) and EPCs were collected for analysis. Results: the increased extracellular ROS in BM, serum and blood intracellular ROS production in the mice with oxLDL treatment in association with a significant reduction of circulating MNCs and EPCs were restored with Probucol treatment. A significant increase in the serum ox-LDL and C-reactive protein and decrease in superoxide dismutase and circulating MNCs and EPCs were observed
\end{abstract}

Yuqi Cui, MD, PhD.

or Zhenguo Liu, MD, PhD.

KARGER
324 Jingwuweiqi Road, Jinan, Shandong 250021, (China.) or Davis Heart \& Lung Research Institute, The Ohio State University Wexner Medical Center, Room 200 DHLRI, 473 W $12^{\text {th }}$ Ave, Columbus, OH 43210, (USA)

E-Mail burningmoon2442@hotmail.com or E-Mail zhenguo.liu@osumc.edu 


\section{Cellular Physiology Cell Physiol Biochem 2016;39:89-101 \begin{tabular}{l|l} 
and Biochemistry Published online: June 20, 2016 & $\begin{array}{l}\text { C } 2016 \text { The Author(s). Published by S. Karger AG, Basel } \\
\text { www.karger.com/cpb }\end{array}$
\end{tabular} \\ Zhang et al.: Probucol Protects EPC Against ox-LDL}

in hyperlipidemic patients that were effectively reversed with probucol treatment. Conclusion: these data suggested that probucol could protect EPCs from ox-LDL through inhibition of ROS production in vivo.

(C) 2016 The Author(s)

Published by S. Karger AG, Basel

\section{Introduction}

Endothelial injury or dysfunction has been considered as an initial trigger of the development of atherosclerosis [1-4]. Endothelial progenitor cells (EPCs), as an important cell population in the bone marrow and blood mononuclear cells (MNCs), play a critical role in angiogenesis, endothelial repair, vascular re-endothelialization, and prevention of neointima formation [5-7]. The number of circulating EPCs is significantly decreased in patients with atherosclerosis or coronary artery disease (CAD) $[8,9]$. Oxidized low-density lipoprotein (ox-LDL), a key component in hyperlipidemic state, has been implicated in the formation of atherosclerotic plaques. Both clinical and animal studies have shown that oxLDL level was significantly elevated in hyperlipidemia [10]. There are extensive interactions between ox-LDL and a variety of cells through multiple mechanisms. The biological effects of ox-LDL on its target cells are highly variable and complex, depending on the individual cell type [11-20]. Ox-LDL was reported to inhibit EPC proliferation, differentiation, and suppress EPCs function including inhibition of cell migration, adhesion and in vitro vasculogenesis as well as ischemia-induced neovascularization in vivo [17, 21-24].

Reactive oxygen species (ROS) plays a critical role in the development of atherosclerosis [25-27]. It was demonstrated that a significant amount of ROS was produced spontaneously from ox-LDL at clinically relevant concentrations, and was involved in the action of ox-LDL on human umbilical vein endothelial cells [28, 29], bone marrow (BM) stem cells [30], vascular smooth muscle cells [31], monocytes [32], macrophage [33] and foam cells [34]. Treatment with ox-LDL increased intracellular ROS generation in cultured endothelial cells [35]. Our previous study showed that intravenous injection of ox-LDL could induce ROS formation in murine BM and blood [36]. It is well known that antioxidant enzyme superoxide dismutase (SOD) could attenuate ROS generation in vivo and in vitro [36], while SOD deficiency leads to increased ROS production and endothelial dysfunction with nitroglycerin-induced tolerance [37]. Plasma C-reactive protein (CRP) is known as a pro-inflammatory marker [38], and is associated with ROS generation [39] and SOD activities [40]. Therefore, SOD and CRP were used as an indirect evidence for ROS production as well.

Probucol, as a diphenolic compound with anti-oxidant and anti-inflammatory properties, could decrease atherosclerosis and restenosis in coronary arteries [41]. It has been reported that probucol could preserve endothelial function by enhancing prostacyclin generation [42], reducing the level of endogenous nitric oxide (NO) synthase inhibitor [43], and inhibiting the expression of various adhesion molecules [44]. Probucol could also promote proliferation [42] and reduce apoptosis of endothelial cells that induced by oxidative injury [45-47]. Impaired ischemia-induced neovascularization by cigarette smoke could also be rescued by probucol via improved function of EPCs [48]. Probucol treatment could also protect EPCs from oxidized high-density lipoprotein (ox-HDL)-induced apoptosis [49]. The present study aimed to determine whether probucol could have protective effects on circulating MNCs and EPCs in mouse treated with ox-LDL and in hyperlipidemic patients with elevated ox-LDL level. We observed that probucol could rescue the decreased population of circulating MNCs and EPCs by ox-LDL in mouse and in hyperlipidemic patients with increased level of ox-LDL.

\section{Materials and Methods}

Ox-LDL preparation

Following Institutional Review Board approval and obtaining informed consent, blood samples were collected in heparinized tubes from healthy volunteers for the study. Plasma was obtained with centrifugation 


\section{Cellular Physiology Cell Physiol Biochem 2016;39:89-101 and Biochemistry Published online: June 20, $2016 \quad \begin{aligned} & \text { DOI: 10.1159/000445608 } 2016 \text { The Author(s). Published by S. Karger AG, Basel } \\ & \text { www.karger.com/cpb }\end{aligned}$ \\ Zhang et al.: Probucol Protects EPC Against ox-LDL}

at $1500 \mathrm{~g}$ for $20 \mathrm{~min}$. Lipoproteins were isolated from the plasma by sequential ultracentrifugation using a Beckman TL-100 tabletop ultracentrifuge (Beckman, Palo Alto, CA) as described [50]. The isolated lipoproteins were dialyzed against $0.3 \mathrm{mM}$ EDTA in $1 \times$ phosphate-buffered saline (PBS, pH 7.4) overnight and subsequently filter-sterilized with $0.22 \mu \mathrm{M}$ filter. The protein concentration in the lipoproteins was determined using the Lowry's method. Ox-LDL was produced from the native LDL immediately after dialysis using $5 \mu \mathrm{M}$ copper sulphate, and was stopped by adding EDTA ( $0.25 \mathrm{mM}$, final concentration) as described [51].

Animal models

All animal experiments were performed in accordance with the Guide for the Care and Use of Laboratory Animals published by the U.S. National Institute of Health (NIH Publication no. 85-23, revised 1996). The experimental protocols were reviewed and approved by the Institutional Animal Care and Use Committee of the Ohio State University Wexner Medical Center, Columbus, OH, USA. Twenty-four wild type male C57 BL/6 mice (4-6 weeks old, Jackson Lab, ME, USA) were divided randomly into control group, oxLDL treatment group, and probucol group. The mice in ox-LDL treatment group and probucol group were given $50 \mu \mathrm{g}$ ox-LDL via tail vein injection (once daily for 3 days), while the mice in control group were given equal volume of PBS (once daily for 3 days). For the probcol group, probcol was first dissolved in $99 \%$ ethanol and then diluted in PBS. The prepared probucol was used to pre-treat the mice (500 mg/kg/d) 24 hours before ox-LDL injection and daily for 3 days with ox-LDL treatment via intragastric administration.

Intracellular and extracellular ROS detection

Blood was harvested from the mice after intravenous injection with PBS (control) or ox-LDL (50 $\mu$ ) with or without probucol treatment for 3 days. Red blood cells (RBC) were eliminated using RBC lysis as described [36]. The blood intracellular ROS formation was determined as described [36]. Plasma and BM fluid were collected for extracellular ROS detection using electron paramagnetic resonance (EPR) as described [36].

\section{Murine MNCs, EPCs and human EPCs analysis}

After collection of BM and blood cells, MNCs were isolated as described [52]. Cell surface markers CD34, Flk-1 and KDR were used to identify EPCs. The cells positive for CD34+/Flk- $1^{+}$were identified as EPCs for mice, and the cells positive for $\mathrm{CD}_{3} 4^{+} / \mathrm{KDR}^{+}$were considered as EPCs for patients. Mouse Flk-1 APC-Cy7 and mouse CD34 FITC were obtained from Becton Dickinson Biosciences (NJ, USA) and eBioscience (San Diego, CA, USA) respectively, while the other antibodies were purchase from Biolegend (San Diego, CA, USA). After elimination of RBC, flow cytometry analysis was performed to identify EPCs using the LSRII system (Becton Dickinson Biosciences, NJ, USA).

Patient selection and human ox-LDL measurement

The patient study was conducted at the Shandong Provincial Hospital, Shandong University, Jinan, China. The protocol was reviewed and approved by the university ethical review board. All patients provided their written informed consent. A total of 10 patients who had CAD and hyperlipidemia with age of at least 21 years old were recruited into the study. Age- and sex-matched healthy volunteers were recruited as the control. Patients were randomly divided into 2 groups with 5 patients in each group: probucol treatment group and placebo control. Age-matched healthy volunteers were recruited as healthy control. Baseline fasting lipid profile, serum ox-LDL level, blood glucose, C-reactive protein (CRP), superoxide dismutase (SOD), thyroid stimulating hormone (TSH), kidney and liver functions were obtained from all the patients. Patients in the probucol treatment group received $500 \mathrm{mg}$ probucol twice a day orally for 7 days with no further treatment afterwards, while the patients in the control group were given placebo. The patients and the treating physicians had no knowledge on what they received (double blind). After one week of treatment and one week after discontinuing probucol, blood samples were collected to determine the fasting lipid profile, serum ox-LDL level, blood glucose, CRP, SOD, TSH, kidney and liver functions, as well as the populations of circulating MNCs and EPCs. The patients' lipid profile was determined using an ARCHITECT ci16200 Integrated System (Abbott, Illinois, US) and an electrochemiluminescent procedure (Cobas E601; Roche, Basel, Switzerland). Patients' plasma ox-LDL was measured using human ox-LDL ELISA kit (Blue Gene, Shanghai, China). 


\section{Cellular Physiology Cell Physiol Biochem 2016;39:89-101 \begin{tabular}{ll|l} 
and Biochemistry & Dublished online: June 20,2016 & $\begin{array}{l}\text { C } 2016 \text { The Author(s). Published by S. Karger AG, Basel } \\
\text { www.karger.com/cpb }\end{array}$
\end{tabular} \\ Zhang et al.: Probucol Protects EPC Against ox-LDL}

\section{Statistical analysis}

All the data were presented as means \pm standard deviation (SD), and statistically analyzed using unpaired Student t-test (two-sided) for two groups of data or two way ANOVA (analysis of variance) (PRISM Version 5.0.; GraphPad Software, Inc., San Diego, CA) followed by post hoc conservative Bonferroni's test for three groups of data to minimize type I error as appropriate. Normal distribution of data was tested using the Shapiro-Wilk $W$-test, and equal variance was tested using the $F$-test. When the null hypothesis of normality and/or equal variance was rejected, the non-parametric Mann-Whitney $U$-test was used. The differences were considered statistically significant when a two-tailed $\mathrm{p}<0.05$.

\section{Result}

Probucol prevented ox-LDL-mediated reduction of BM mononuclear cells and circulating EPCs

To determine the effects of ox-LDL on EPCs, we first injected 50 $\mu \mathrm{g}$ human ox-LDL into wild-type (WT) mice for 3 days. The populations of BM mononuclear cells (MNCs) and circulating EPCs were significantly decreased in the mice with ox-LDL treatment (Fig.1A and B). To investigate the protective effect of probucol, we pre-treated the mice with probucol prior to the injection of ox-LDL. Probucol effectively prevented ox-LDL-induced reduction in the population of circulating EPCs and BM MNCs.

Probucol attenuated both intracellular and extracellular ROS production

To explore the mechanisms for the action of ox-LDL on circulating EPCs and BM MNCs, we measured both intracellular and extracellular ROS production in the blood and BM.

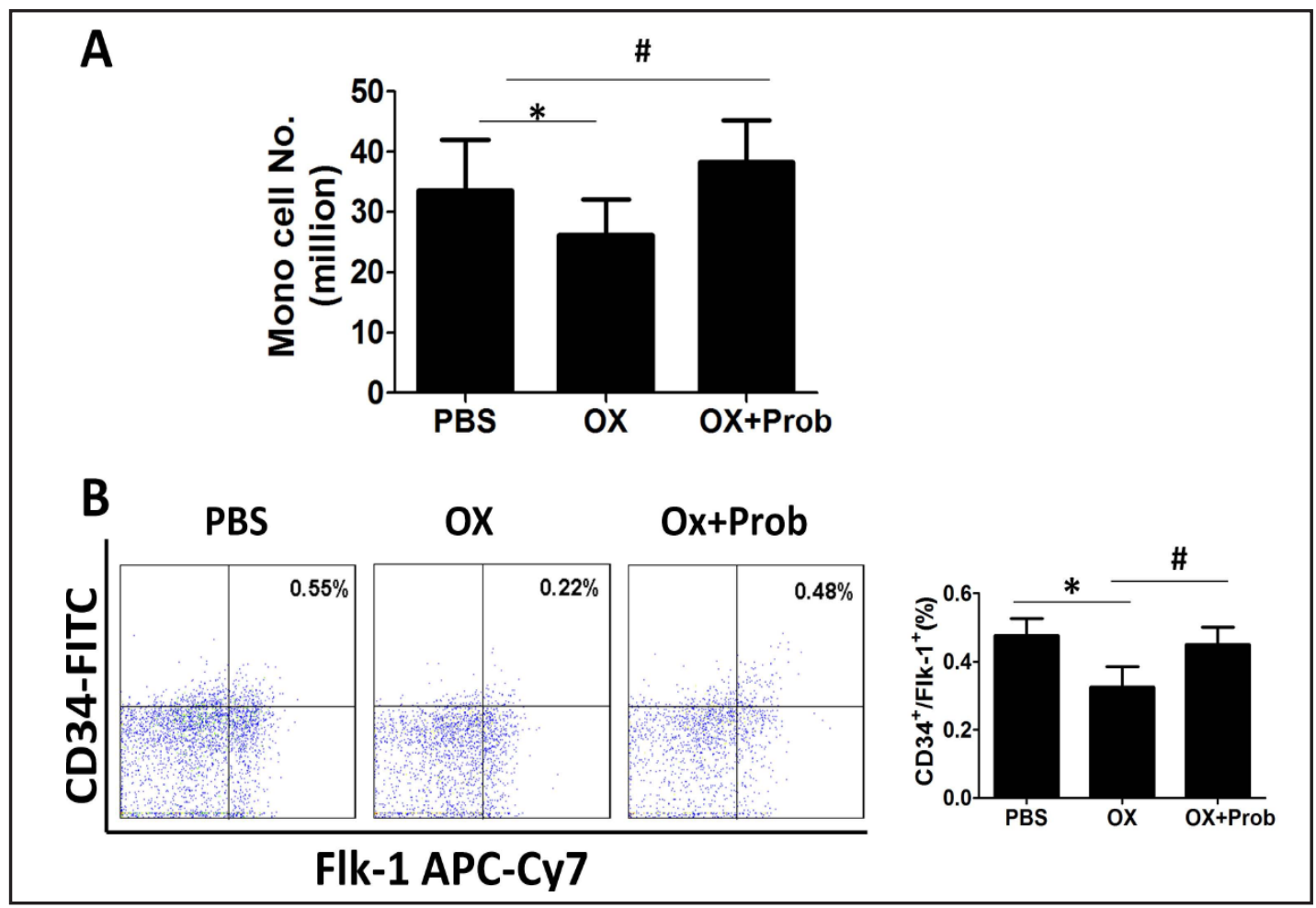

Fig. 1. Probucol rescued the circulating MNCs and EPCs in mouse with ox-LDL treatment. After 3 days of ox-LDL treatment, the circulating MNCs (A) and EPCs (B) were significantly decreased. The decreased EPCs were normalized following probucol treatment. PBS: C57BL/6 mouse with PBS treatment; OX: C57BL/6 mouse with ox-LDL injection; OX+Prob: C57BL/6 mouse with probucol treatment following ox-LDL injection; Mono: mouse mononuclear cell; $\mathrm{M} \mathrm{CD} 34^{+} / \mathrm{Flk}-1^{+}$: mouse CD34 $/$Flk- $1^{+}$cell; SSC-A: side scatter analysis; FSC-A: forward scatter analysis. * PBS vs $\mathrm{OX}, \mathrm{p}<0.05, \mathrm{n}=8$; \# ox vs ox+prob, $\mathrm{p}<0.05, \mathrm{n}=8$. 


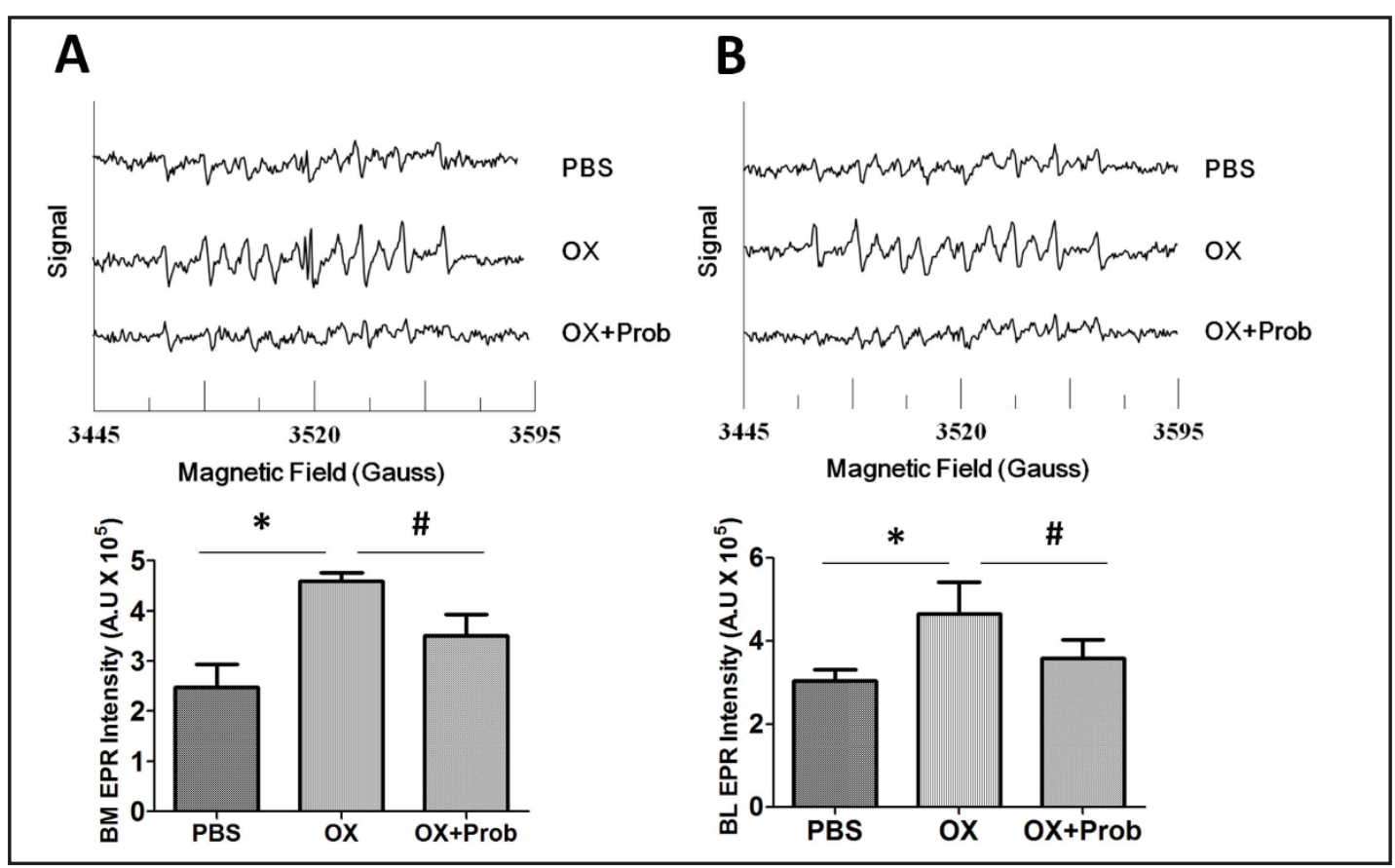

Fig. 2. Ox-LDL-induced extracellular ROS production was completely blocked by probucol. Both BM (A) and blood (B) extracellular ROS levels were significantly increased after ox-LDL injection. Probucol treatment effectively blocked the ROS generation. BM EPR intensity: bone marrow EPR intensity; BL EPR intensity: blood EPR intensity. * PBS vs OX, p<0.05, n=8; \# ox vs ox+prob, $p<0.05, \mathrm{n}=8$.

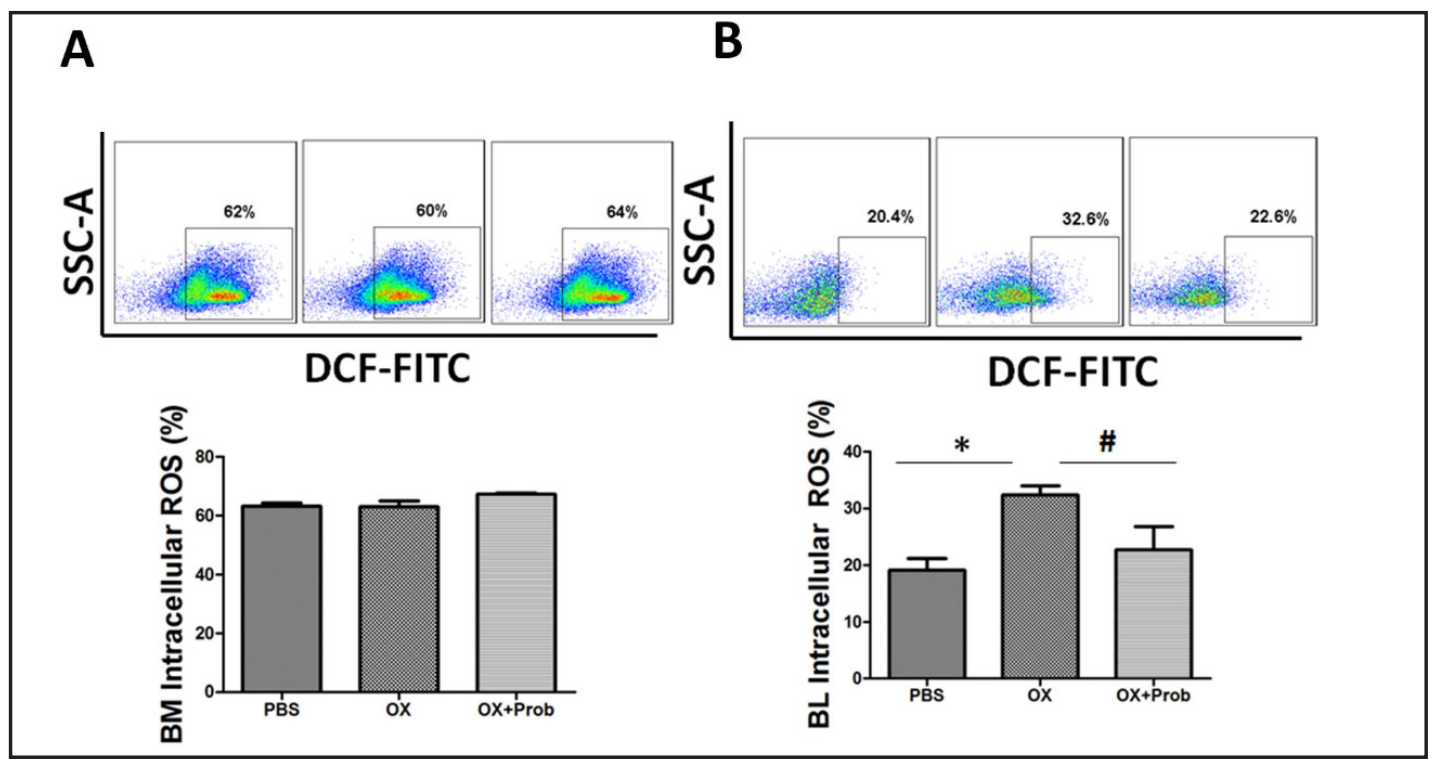

Fig. 3. Ox-LDL-induced blood intracellular ROS production was prevented with probucol treatment. After ox-LDL injection, the blood intracellular ROS production was significantly increased. Probucol effectively blocked the ROS production from ox-LDL. There was no extra ROS production in BM cells with ox-LDL treatment. * PBS vs OX, p<0.05, n=8; \# ox vs ox+prob, $\mathrm{p}<0.05, \mathrm{n}=8$.

Treatment of the mice with ox-LDL significantly increased the extracellular ROS in murine BM and blood cells over 2 folds compared to the control (Fig. 2A and B). The murine blood intracellular ROS level was also significantly elevated in the mice treated with ox-LDL compared to the mice with PBS treatment (Fig. 3B), while there was no change in murine 


\begin{tabular}{|c|c|c|}
\hline \multirow{2}{*}{$\begin{array}{l}\text { Cellular Physiology } \\
\text { and Biochemistrv }\end{array}$} & \multicolumn{2}{|c|}{ Cell Physiol Biochem 2016;39:89-101 } \\
\hline & $\begin{array}{l}\text { DOII } 10.11159 / 000445608 \\
\text { Published onlile: June } 20,2016\end{array}$ & $\begin{array}{l}\text { O } 2016 \text { The Author(s). Published by S. Karger AG, Basel } \\
\text { www.karger.com/cpb }\end{array}$ \\
\hline
\end{tabular}

Table 1. Human plasma lipid profile. Plasma lipid profile was determined in the patients with coronary artery disease and hyperlipidemia with and without probucol treatment. Baseline: Patient without placebo or probucol treatment; Treatment: Patient with placebo or probucol treatment for 7 days; Post treatment: patient stopped treating placebo or probucol for 7 days. HDL: high density lipoprotein; LDL: low density lipoprotein; TRG: triglycerides; TC: total cholesterol

\begin{tabular}{|c|c|c|c|c|c|}
\hline \multirow{3}{*}{ Baseline } & & $\mathrm{HDL}(\mathrm{mmol} / \mathrm{L})$ & $\mathrm{LDL}(\mathrm{mmol} / \mathrm{L})$ & $\mathrm{TG}(\mathrm{mmol} / \mathrm{L})$ & $\mathrm{TC}(\mathrm{mmol} / \mathrm{L})$ \\
\hline & $\begin{array}{l}\text { Placebo } \\
(\text { Mean } \pm \text { SD, } n=5)\end{array}$ & $1.10 \pm 0.24$ & $2.88 \pm 0.54$ & $1.70 \pm 0.14$ & $4.85 \pm 0.92$ \\
\hline & $\begin{array}{l}\text { Prob } \\
(\text { Mean } \pm S D, n=5)\end{array}$ & $0.96 \pm 0.14$ & $2.91 \pm 0.62$ & $2.07 \pm 0.84$ & $4.80 \pm 0.92$ \\
\hline \multirow[t]{2}{*}{ Treatment } & $\begin{array}{l}\text { Placebo } \\
(\text { Mean } \pm S D, n=5)\end{array}$ & $1.25 \pm 0.22$ & $2.57 \pm 0.68$ & $1.74 \pm 0.15$ & $4.92 \pm 0.81$ \\
\hline & $\begin{array}{l}\text { Prob } \\
(\text { Mean } \pm \text { SD, } n=5)\end{array}$ & $0.85 . \pm 0.22$ & $2.27 \pm 0.77$ & $2.29 \pm 0.58$ & $4.00 \pm 1.51$ \\
\hline \multirow[t]{2}{*}{ Post treatment } & $\begin{array}{l}\text { Placebo } \\
(\text { Mean } \pm S D, n=5)\end{array}$ & $1.25 \pm 0.21$ & $2.81 \pm 0.72$ & $1.55 \pm 0.14$ & $5.14 \pm 0.62$ \\
\hline & $\begin{array}{l}\text { Prob } \\
(\text { Mean } \pm S D, n=5)\end{array}$ & $0.98 . \pm 0.25$ & $2.46 \pm 0.87$ & $1.72 \pm 0.58$ & $4.07 \pm 1.39$ \\
\hline
\end{tabular}

BM intracellular ROS level (Fig. 3A). Pre-treatment with probucol effectively blocked the production of extracellular ROS in the BM and blood as well as intracellular blood ROS production in the mice treated with ox-LDL as shown in Fig. 2 and Fig. 3.

Probucol treatment decreased serum ox-LDL level and rescued circulating EPCs in hyperlipidemic patients

To study the effect of probucol on ox-LDL and EPCs in human, we measured the plasma lipid profile in patients with hyperlipidemia with and without probucol treatment. LDL, non-HDL lipoprotein, and ox-LDL were all significantly increased in the patients with hyperlipidemia over the age- and sex-matched healthy individuals (controls) as expected (Table 1). After one week of probucol treatment, there were no significant changes in serum LDL, non-HDL lipoprotein levels, blood glucose, TSH, kidney and liver functions in the patients (data not shown). However, the serum ox-LDL was significantly decreased in the patients with probucol treatment as compared with the placebo group. Decreased level of serum oxLDL was still present in the patients one week after discontinuation of probucol (Fig. 4). In parallel to decreased serum ox-LDL level, the level of circulating EPCs was partially and yet significantly rescued in the patients with probucol treatment compared with the placebo group. The level of EPCs maintained at a higher level in the patients one week after probucol discontinuation as shown in Fig. 5.

Probucol increased plasma SOD and decreased CRP levels in hyperlipidemic patients

Since SOD and CRP are associated with ROS production, we measured plasma SOD and CRP levels in the hyperlipidemic patients with and without probucol treatment. The plasma SOD was significantly increased while CRP was significantly reduced in the patients with one week of probucol treatment as compared with the placebo group. The effect of probucol on SOD and CRP persisted in the patients one week after discontinuation of probucol treatment (Fig. 6).

\section{Discussion}

In the present study, we demonstrated that probucol reversed the effects of ox-LDL on circulating MNCs and EPCs, and effectively prevented ox-LDL-induced increase in BM and 
Fig. 4. Probucol treatment decreased plasma oxLDL level in hyperlipidemic patients. Plasma ox-LDL level was measured using ELISA in the patients with documented coronary artery disease (CAD) and hyperlipidemia with and without probucol treatment. The serum ox-LDL level was significantly elevated in the patients with hyperlipidemia as compared with the healthy volunteers. Probucol treatment significantly decreased the serum ox-LDL level in the patients. The serum ox-LDL remained at the decreased level in the patients one week after discontinuation of probucol. Healthy Ctrl: healthy volunteer as control group. Placebo: hyperlipidemic patients with placebo treatment. Prob: hyperlipidemic patients with probucol treatment. * placebo treatment vs healthy control, $\mathrm{P}<0.05, \mathrm{n}=5$; ** probucol treatment vs healthy control, $\mathrm{p}<0.05, \mathrm{n}=5$; \# probucol treatment vs placebo, $\mathrm{p}<0.05, \mathrm{n}=5$.

Fig. 5. Probucol treatment partially rescued EPCs in hyperlipidemic patients. The EPCs level was significantly decreased in patients with hyperlipidemia, while the declined EPCs were partially rescued with probucol treatment and post treatment for 1 week respectively. * placebo treatment vs healthy control, $\mathrm{P}<0.001, \mathrm{n}=5$; ** probucol treatment vs healthy control, $\mathrm{p}<0.001, \mathrm{n}=5$; \# probucol treatment vs placebo, $\mathrm{p}<0.001, \mathrm{n}=5$.
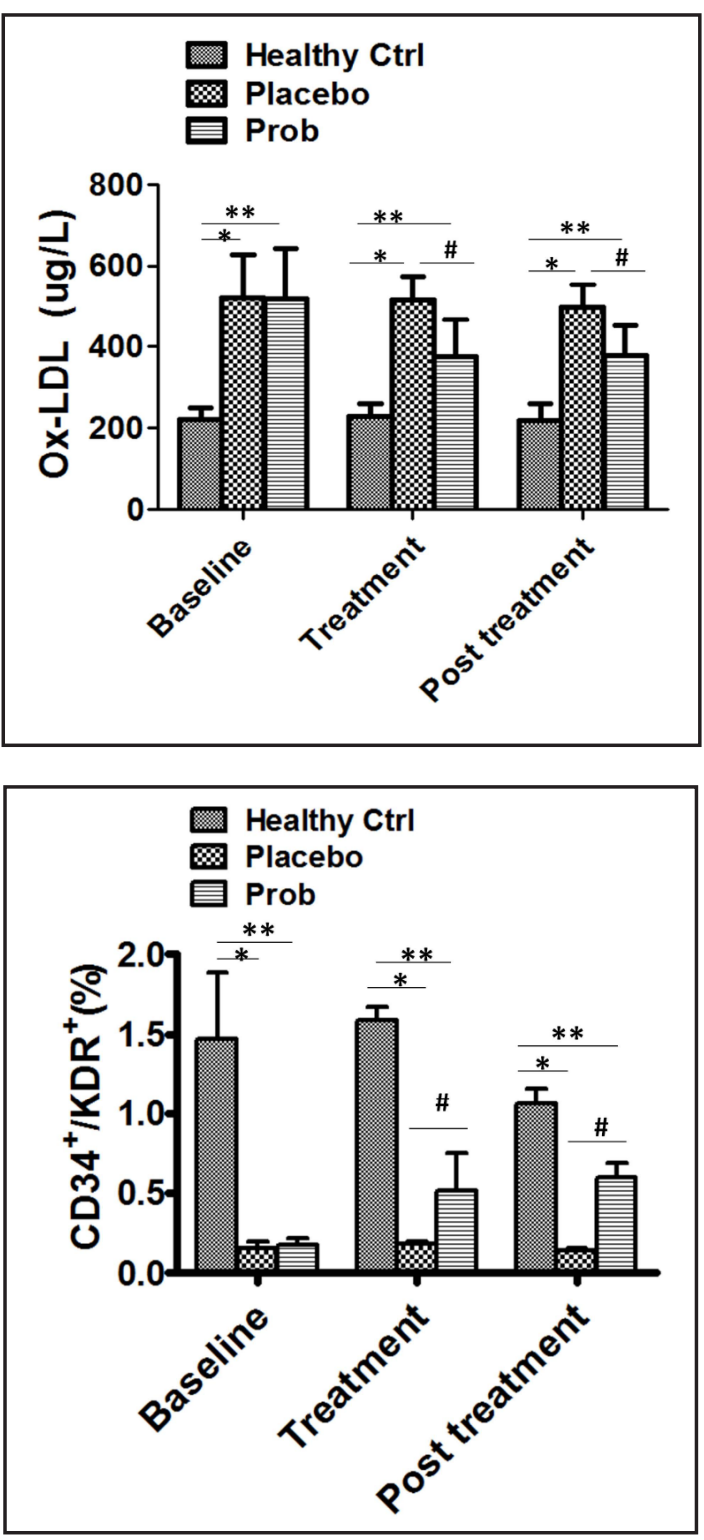

blood extracellular ROS and blood intracellular ROS levels in mouse. Probucol treatment partially rescued the diminished EPCs level in patients with hyperlipidemia in association with reduction of ox-LDL and CRP and increase in SOD level.

It has been shown that ox-LDL significantly impairs the function, survival and proliferation of stem cells and progenitor cells [53]. Ox-LDL induces senescence [54], accelerates the ageing of hematopoietic stem cells in vivo [55], and inhibits their proliferation, migration, adhesion and differentiation [17, 30, 53, 56, 57]. Previous studies showed that the number of circulating EPCs was inversely correlated with total cholesterol, LDL-cholesterol and ox-LDL levels $[11,58-60]$. However, Zhang et al. reported that the transmigration rates of BM mesenchymal stem cells (MSCs) and cell-cell adhesion between BM MSCs and MCs were significantly increased with ox-LDL treatment in a dose- and time-dependent manner [61]. Our previous [36] and present studies demonstrated that ox-LDL could significantly decrease both circulating MNCs and EPCs levels.

Ox-LDL significantly decreased the proliferation, migration, and adhesion capacity of EPCs via increased ROS formation [62]. It was reported that a significant amount of ROS was produced spontaneously from ox-LDL in vitro and in vivo $[53,63]$. ROS and oxidative 

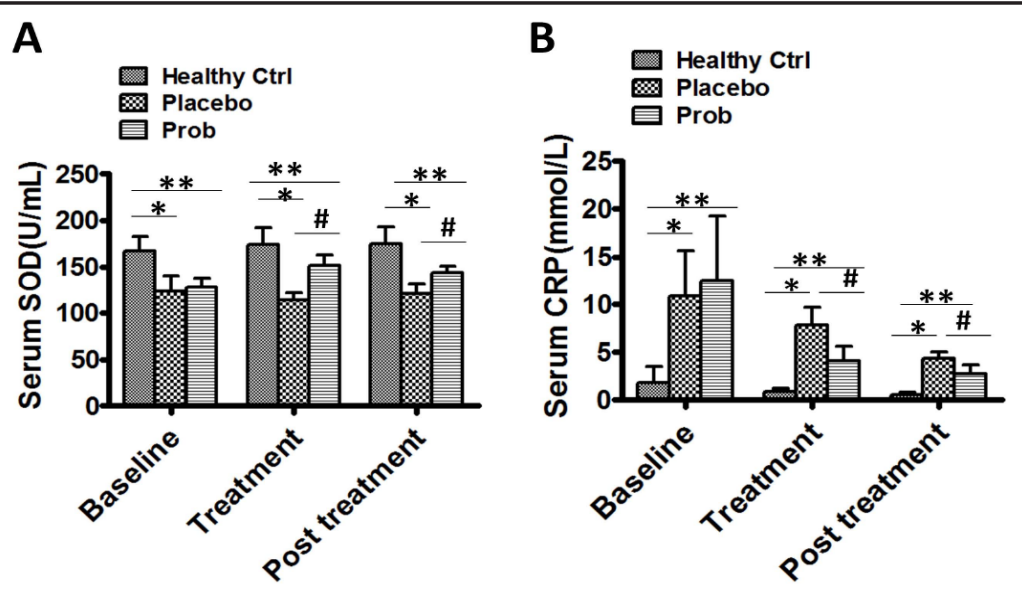

Fig. 6. Probucol treatment decreased plasma CRP and increased SOD level in hyperlipidemic patients. The plasma SOD level was significantly decreased and CRP was notably increased in patients with hyperlipidemia. Probucol partially reversed the effects of hyperlipidemia on plasma SOD and CRP in the patients with hyperlipidemia. SOD: superoxide dismutase. CRP: C-reactive protein. * placebo treatment vs healthy control, $\mathrm{P}<0.05, \mathrm{n}=5$; ** probucol treatment vs healthy control, $\mathrm{p}<0.05, \mathrm{n}=5$; \# probucol treatment vs placebo, $\mathrm{p}<0.05, \mathrm{n}=5$.

stress were involved in EPC dysfunction in many diseases including hyperlipidemia, diabetes, coronary artery disease, renal ischemia-reperfusion injury and air pollution related cardiovascular disease [64-67]. Our data showed that ox-LDL was able to increase both BM and blood extracellular and blood intracellular ROS levels in mouse with ox-LDL treatment. In addition, ox-LDL and hyperlipidemia-induced reduction in EPCs in BM and blood were associated with ROS production [36]. On the other hand, antioxidant enzyme SOD could attenuate ROS generation in vivo and in vitro [36], thus SOD deficiency leads to increased ROS production and endothelial dysfunction during nitroglycerin tolerance [37]. In addition, plasma CRP is known as a pro-inflammatory marker [38], and is associated with ROS generation [39] and SOD activities [40]. Therefore, we used SOD and CRP as an indirect evidence for ROS production in the patient study. We found that the SOD was significantly decreased while CRP was increased in patients with hyperlipidemia.

Several studies reviewed the protective reagents and methods for EPCs including tripterine, urinary trypsin inhibitor, microRNA-130a, interruption of CD40 pathway, and GMCSF [68-71]. As a cholesterol-lowering medicine originally, probucol significantly inhibits the initiation and development of atherosclerosis via multiple mechanisms including suppressing ROS formation [72-74], rescuing endothelial function [75-77], inhibiting the activation and adhesion of monocytes [78], attenuating growth and migration of VSMCs [76, 79,80 ], altering proliferation and apoptosis of VSMCs [80-82] and macrophages [83], as well as decreasing cytokine secretion in macrophages of [84]. Probucol prevents LDL oxidation [85, 86], increases SOD level and activity [87], decreases the levels of ox-LDL and CRP [72]. Probucol has been reported to rescue cigarette smoke-induced impairment of ischemiainduced neovascularization by improving the function of EPCs [48], and protect EPCs from oxidized high-density lipoprotein (ox-HDL) [49]. Additionally, it has been reported that probucol is able to prevent ROS-induced inactivation of endothelium-derived NO [88], reduce endogenous NO synthase inhibitor [43], and increase the level and function of NO, which could regulate the self-renewal, viability, migration, proliferation, and differentiation of EPCs [89]. In the present study, we observed that probucol effectively preserved the populations of circulating MNCs and EPCs and blocked ROS formation in the mice with ox-LDL treatment. In the human study, EPCs were partially rescued in association with decreased levels of oxLDL and CRP and increased level of SOD following probucol treatment in the patients with hyperlipidemia.

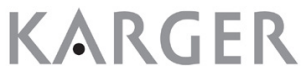




\section{Cellular Physiology Cell Physiol Biochem 2016;39:89-101

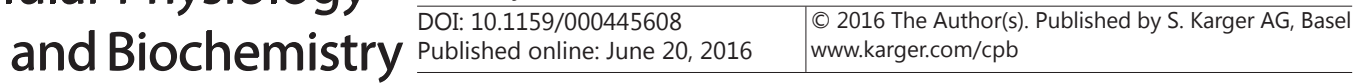 \\ Zhang et al.: Probucol Protects EPC Against ox-LDL}

Fig. 7. Possible mechanisms on the beneficial effect of probucol on circulating EPCs in hyperlipidemia. Ox-LDL and CRP levels were increased, and SOD was decreased in the hyperlipidemic state in vivo. A significant amount of ROS was produced with elevated oxLDL and CRP level and decreased SOD levels in vivo which could contribute to the decreased level of EPCs. Probucol decreased the levels of ox-LDL and CRP, increased the level of SOD, leading to decreased ROS generation. Probucol as an antioxidant could also inhibit ROS production directly. The combined outcome of the protective effects of probucol could normalize the population of EPCs that was decreased with ox-LDL treatment or in hyperlipidemia. -: diminish; $\downarrow$ : decrease; $\uparrow:$ increase.

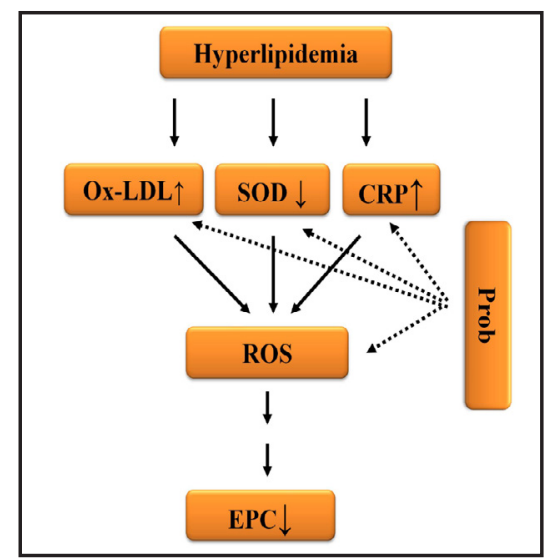

The mechanisms for the protective effects of probucol on ox-LDL-mediated reduction of EPCs are very complex, and many mechanisms are still unknown. Although our present study showed that probucol rescued EPCs through inhibition of ROS production from ox-LDL, there are many questions that need to be addressed. For example, does probucol also protect BM stem cells which are the main source of EPCs? Does probucol affect the proliferation and/or apoptosis of EPCs? Can probucol restore the function of EPCs impaired by ox-LDL? Does ox-LDL trigger autophagy of EPCs? If so, can probucol prevent this process? All these questions require further studies.

In conclusion, data from the present study demonstrated that probucol effectively reversed the effects of ox-LDL on circulating MNCs and EPCs in mouse via inhibition of BM and blood extracellular ROS and blood intracellular ROS production. For human study, probucol partially rescued the diminished EPCs level in hyperlipidemic patients in association with reduction of ox-LDL and CRP and increase in SOD level (Fig. 7).

\section{Acknowledgment}

This work was supported by a U.S. NIH grants to ZL (NIH R01 HL094650 and R01 HL124122) and Shandong Provincial Science and Technology Development Grants to LC (2010GSF10272 and 2008GG3002018).

\section{Disclosure Statement}

None.

\section{References}

1 Blankenberg S, Barbaux S, Tiret L: Adhesion molecules and atherosclerosis. Atherosclerosis 2003;170:191203.

2 Harrison DG: Endothelial dysfunction in atherosclerosis. Basic Res Cardiol 1994;89:S87-102.

3 Vanhoutte PM: Endothelial dysfunction and atherosclerosis. Eur Heart J 1997;18:S E19-29.

4 Davignon J, Ganz P: Role of endothelial dysfunction in atherosclerosis. Circulation 2004;109:III27-32.

5 Lin YL, Yet SF, Hsu YT, Wang GJ, Hung SC: Mesenchymal stem cells ameliorate atherosclerotic lesions via restoring endothelial function. Stem Cells Transl Med 2015;4:44-55.

6 De Winter RJ, Klomp M: Understanding the role of endothelial progenitor cells in cardiovascular disease, coronary artery lesion progression, and in-stent restenosis. JACC Cardiovasc Interv 2010;3:87-89.

7 Xu BY, Xiang MX, Wang JA: Endothelial progenitor cells and in-stent restenosis. Curr Stem Cell Res Ther 2015;10:364-731.

8 Kunz GA, Liang G, Cuculi F, Gregg D, Vata KC, Shaw LK, Goldschmidt-Clermont PJ, Dong C, Taylor DA, Peterson ED: Circulating endothelial progenitor cells predict coronary artery disease severity. Am Heart J 2006;152:190-195. 


\section{Cellular Physiology Cell Physiol Biochem 2016;39:89-101 \begin{tabular}{ll|l} 
DOI: 10.1159/000445608 & $\begin{array}{l}\text { O 2016 The Author(s). Published by S. Karger AG, Basel } \\
\text { www.karger.com/cpb }\end{array}$
\end{tabular} \\ Zhang et al.: Probucol Protects EPC Against ox-LDL}

9 Wang HY, Gao PJ, Ji KD, Shen WF, Fan CL, Lu L, Zhu DL: Circulating endothelial progenitor cells, c-reactive protein and severity of coronary stenosis in chinese patients with coronary artery disease. Hypertens Res 2007;30:133-141.

10 Owens AP, 3rd, Passam FH, Antoniak S, Marshall SM, McDaniel AL, Rudel L, Williams JC, Hubbard BK, Dutton JA, Wang J, Tobias PS, Curtiss LK, Daugherty A, Kirchhofer D, Luyendyk JP, Moriarty PM, Nagarajan S, Furie BC, Furie B, Johns DG, Temel RE, Mackman N: Monocyte tissue factor-dependent activation of coagulation in hypercholesterolemic mice and monkeys is inhibited by simvastatin. J Clin Invest 2012;122:558-568.

11 Chen JZ, Zhang FR, Tao QM, Wang XX, Zhu JH, Zhu JH: Number and activity of endothelial progenitor cells from peripheral blood in patients with hypercholesterolaemia. Clin Sci (Lond) 2004;107:273-280.

12 Yang CM, Chiu CT, Wang CC, Chien CS, Hsiao LD, Lin CC, Tu MT, Pan SL: Activation of mitogen-activated protein kinase by oxidized low-density lipoprotein in canine cultured vascular smooth muscle cells. Cell Signal 2000;12:205-214.

13 Hundal RS, Salh BS, Schrader JW, Gomez-Munoz A, Duronio V, Steinbrecher UP: Oxidized low density lipoprotein inhibits macrophage apoptosis through activation of the pi 3-kinase/pkb pathway. J Lipid Res 2001;42:1483-1491.

14 Namgaladze D, Kollas A, Brune B: Oxidized ldl attenuates apoptosis in monocytic cells by activating erk signaling. J Lipid Res 2008;49:58-65.

15 Hamilton J, Myers D, Jessup W, Cochrane F, Byrne R, Whitty G, Moss S: Oxidized ldl can induce macrophage survival, DNA synthesis, and enhanced proliferative response to csf- 1 and gm-csf. Arterioscler Thromb Vasc Biol 1999;19:98-105.

16 Matsumura T, Sakai M, Kobori S, Biwa T, Takemura T, Matsuda H, Hakamata H, Horiuchi S, Shichiri M: Two intracellular signaling pathways for activation of protein kinase c are involved in oxidized low-density lipoprotein-induced macrophage growth. Arterioscler Thromb Vasc Biol 1997;17:3013-3020.

17 Wang X, Chen J, Tao Q, Zhu J, Shang Y: Effects of ox-ldl on number and activity of circulating endothelial progenitor cells. Drug Chem Toxicol 2004;27:243-255

18 Chen XP, Xun KL, Wu Q, Zhang TT, Shi JS, Du GH: Oxidized low density lipoprotein receptor-1 mediates oxidized low density lipoprotein-induced apoptosis in human umbilical vein endothelial cells: Role of reactive oxygen species. Vascul Pharmacol 2007;47:1-9.

19 Galle J, Heinloth A, Wanner C, Heermeier K: Dual effect of oxidized ldl on cell cycle in human endothelial cells through oxidative stress. Kidney Int Suppl 2001;78:S120-123.

20 Seibold S, Schurle D, Heinloth A, Wolf G, Wagner M, Galle J: Oxidized ldl induces proliferation and hypertrophy in human umbilical vein endothelial cells via regulation of p27kip1 expression: Role of rhoa. J Am Soc Nephrol 2004;15:3026-3034.

21 Zhou B, Ma FX, Liu PX, Fang ZH, Wang SL, Han ZB, Poon MC, Han ZC: Impaired therapeutic vasculogenesis by transplantation of oxldl-treated endothelial progenitor cells. J Lipid Res 2007;48:518-527.

22 Imanishi T, Hano T, Sawamura T, Nishio I: Oxidized low-density lipoprotein induces endothelial progenitor cell senescence, leading to cellular dysfunction. Clin Exp Pharmacol Physiol 2004;31:407-413.

23 Imanishi T, Hano T, Matsuo Y, Nishio I: Oxidized low-density lipoprotein inhibits vascular endothelial growth factor-induced endothelial progenitor cell differentiation. Clin Exp Pharmacol Physiol 2003;30:665-670.

24 Ma FX, Zhou B, Chen Z, Ren Q, Lu SH, Sawamura T, Han ZC: Oxidized low density lipoprotein impairs endothelial progenitor cells by regulation of endothelial nitric oxide synthase. J Lipid Res 2006;47:12271237.

25 Victor VM, Rocha M, Sola E, Banuls C, Garcia-Malpartida K, Hernandez-Mijares A: Oxidative stress, endothelial dysfunction and atherosclerosis. Curr Pharm Des 2009;15:2988-3002.

26 Goncharov NV, Avdonin PV, Nadeev AD, Zharkikh IL, Jenkins RO: Reactive oxygen species in pathogenesis of atherosclerosis. Curr Pharm Des 2015;21:1134-1146.

27 Li H, Horke S, Forstermann U: Vascular oxidative stress, nitric oxide and atherosclerosis. Atherosclerosis 2014;237:208-219.

28 Xu H, Duan J, Wang W, Dai S, Wu Y, Sun R, Ren J: Reactive oxygen species mediate oxidized low-density lipoprotein-induced endothelin-1 gene expression via extracellular signal-regulated kinase in vascular endothelial cells. J Hypertens 2008;26:956-963. 


\section{Cellular Physiology Cell Physiol Biochem 2016;39:89-101 \begin{tabular}{l|l} 
and Biochemistry Published online: June 20,2016 & $\begin{array}{l}\text { D) } 2016 \text { The Author(s). Published by S. Karger AG, Basel } \\
\text { www.karger.com/cpb }\end{array}$ \\
\hline
\end{tabular} \\ Zhang et al.: Probucol Protects EPC Against ox-LDL}

29 Zhao W, Ma G, Chen X: Lipopolysaccharide induced lox-1 expression via tlr4/myd88/ros activated p38mapk-nf-kappab pathway. Vascul Pharmacol 2014;63:162-172.

30 Li X, Xiao Y, Cui Y, Tan T, Narasimhulu CA, Hao H, Liu L, Zhang J, He G, Verfaillie CM, Lei M, Parthasarathy S, Ma J, Zhu H, Liu Z: Cell membrane damage is involved in the impaired survival of bone marrow stem cells by oxidized low-density lipoprotein. J Cell Mol Med 2014;18:2445-2453.

31 Sun Y, Chen X: Ox-ldl-induced lox-1 expression in vascular smooth muscle cells: Role of reactive oxygen species. Fundam Clin Pharmacol 2011;25:572-579.

32 Ermak N, Lacour B, Drueke TB, Vicca S: Role of reactive oxygen species and bax in oxidized low density lipoprotein-induced apoptosis of human monocytes. Atherosclerosis 2008;200:247-256.

33 Lee CF, Qiao M, Schroder K, Zhao Q Asmis R: Nox4 is a novel inducible source of reactive oxygen species in monocytes and macrophages and mediates oxidized low density lipoprotein-induced macrophage death. Circ Res 2010;106:1489-1497.

34 Huang H, Koelle P, Fendler M, Schrottle A, Czihal M, Hoffmann U, Conrad M, Kuhlencordt PJ: Induction of inducible nitric oxide synthase (inos) expression by oxldl inhibits macrophage derived foam cell migration. Atherosclerosis 2014;235:213-222.

35 Cominacini L, Garbin U, Pasini AF, Davoli A, Campagnola M, Pastorino AM, Gaviraghi G, Lo Cascio V: Oxidized low-density lipoprotein increases the production of intracellular reactive oxygen species in endothelial cells: Inhibitory effect of lacidipine. J Hypertens 1998;16:1913-1919.

36 Cui Y, Narasimhulu CA, Liu L, Li X, Xiao Y, Zhang J, Xie X, Hao H, Liu JZ, He G, Cowan PJ, Cui L, Zhu H, Parthasarathy S, Liu Z: Oxidized low-density lipoprotein alters endothelial progenitor cell populations. Front Biosci (Landmark Ed) 2015;20:975-988.

37 Daiber A, Oelze M, Sulyok S, Coldewey M, Schulz E, Treiber N, Hink U, Mulsch A, Scharffetter-Kochanek K, Munzel T: Heterozygous deficiency of manganese superoxide dismutase in mice (mn-sod+/-): A novel approach to assess the role of oxidative stress for the development of nitrate tolerance. Mol Pharmacol 2005;68:579-588.

38 Ridker PM: C-reactive protein and the prediction of cardiovascular events among those at intermediate risk: Moving an inflammatory hypothesis toward consensus. J Am Coll Cardiol 2007;49:2129-2138.

39 Zhong Y, Cheng CF, Luo YZ, Tian CW, Yang H, Liu BR, Chen MS, Chen YF, Liu SM: C-reactive protein stimulates rage expression in human coronary artery endothelial cells in vitro via ros generation and erk/ nf-kappab activation. Acta Pharmacol Sin 2015;36:440-447.

40 Wojciechowska C, Romuk E, Tomasik A, Skrzep-Poloczek B, Nowalany-Kozielska E, Birkner E, Jachec W: Oxidative stress markers and c-reactive protein are related to severity of heart failure in patients with dilated cardiomyopathy. Mediators Inflamm 2014;2014:147040.

41 Yamashita S, Matsuzawa Y: Where are we with probucol: A new life for an old drug? Atherosclerosis 2009;207:16-23.

42 Komatsu S, Sawada S, Tamagaki T, Tsuda Y, Kono Y, Higaki T, Imamura H, Tada Y, Yamasaki S, Toratani A, Sato T, Akamatsu N, Tsuji H, Nakagawa M: Effect of probucol on intracellular ph and proliferation of human vascular endothelial cells. J Pharmacol Toxicol Methods 1999;41:33-41.

43 Jiang JL, Li Ns NS, Li YJ, Deng HW: Probucol preserves endothelial function by reduction of the endogenous nitric oxide synthase inhibitor level. Br J Pharmacol 2002;135:1175-1182.

44 Cominacini L, Garbin U, Pasini AF, Davoli A, Campagnola M, Contessi GB, Pastorino AM, Lo Cascio V: Antioxidants inhibit the expression of intercellular cell adhesion molecule- 1 and vascular cell adhesion molecule-1 induced by oxidized ldl on human umbilical vein endothelial cells. Free Radic Biol Med 1997;22:117-127.

45 Tang X, Yang X, Peng Y, Lin J: Protective effects of lycopene against h2o2-induced oxidative injury and apoptosis in human endothelial cells. Cardiovasc Drugs Ther / sponsored by the International Society of Cardiovasc Drugs Ther 2009;23:439-448.

46 Aoki M, Nata T, Morishita R, Matsushita H, Nakagami H, Yamamoto K, Yamazaki K, Nakabayashi M, Ogihara T, Kaneda Y: Endothelial apoptosis induced by oxidative stress through activation of nf-kappab: Antiapoptotic effect of antioxidant agents on endothelial cells. Hypertension 2001;38:48-55.

47 Ceaser EK, Ramachandran A, Levonen AL, Darley-Usmar VM: Oxidized low-density lipoprotein and 15-deoxy-delta 12,14-pgj2 increase mitochondrial complex i activity in endothelial cells. Am J Physiol Heart Circ Physiol 2003;285:H2298-2308. 


\section{Cellular Physiology Cell Physiol Biochem 2016;39:89-101 \begin{tabular}{l|l|l}
\hline DOI: 10.1159/000445608 2016 & $\begin{array}{l}\text { C) } 2016 \text { The Author(s). Published by S. Karger AG, Basel } \\
\text { www.karger.com/cpb }\end{array}$ \\
\hline
\end{tabular} \\ Zhang et al.: Probucol Protects EPC Against ox-LDL}

48 Turgeon J, Dussault S, Haddad P, Groleau J, Menard C, Michaud SE, Maingrette F, Rivard A: Probucol and antioxidant vitamins rescue ischemia-induced neovascularization in mice exposed to cigarette smoke: Potential role of endothelial progenitor cells. Atherosclerosis 2010;208:342-349.

49 Wu J, He Z, Gao X, Wu F, Ding R, Ren Y, Jiang Q Fan M, Liang C, Wu Z: Oxidized high-density lipoprotein impairs endothelial progenitor cells' function by activation of cd36-mapk-tsp-1 pathways. Antioxid Redox Signal 2015;22:308-324.

50 Chung BH, Wilkinson T, Geer JC, Segrest JP: Preparative and quantitative isolation of plasma lipoproteins: Rapid, single discontinuous density gradient ultracentrifugation in a vertical rotor. J Lipid Res 1980;21:284-291.

51 Chandrakala AN, Sukul D, Selvarajan K, Sai-Sudhakar C, Sun B, Parthasarathy S: Induction of brain natriuretic peptide and monocyte chemotactic protein-1 gene expression by oxidized low-density lipoprotein: Relevance to ischemic heart failure. Am J Physiol Cell Physiol 2012;302:C165-177.

52 Kanof ME, Smith PD, Zola H: Isolation of whole mononuclear cells from peripheral blood and cord blood. Curr Protoc Immunol 2001; Chapter 7:Unit 71.

53 Lu T, Parthasarathy S, Hao H, Luo M, Ahmed S, Zhu J, Luo S, Kuppusamy P, Sen CK, Verfaillie CM, Tian J, Liu Z: Reactive oxygen species mediate oxidized low-density lipoprotein-induced inhibition of oct-4 expression and endothelial differentiation of bone marrow stem cells. Antioxid Redox Signal 2010;13:1845-1856.

54 Zhang XP, Zhang GH, Wang YY, Liu J, Wei Q Xu CY, Wang JW, Wang YP: Oxidized low-density lipoprotein induces hematopoietic stem cell senescence. Cell Biol Int 2013;37:940-948.

55 Tie G, Messina KE, Yan J, Messina JA, Messina LM: Hypercholesterolemia induces oxidant stress that accelerates the ageing of hematopoietic stem cells. J Am Heart Assoc 2014;3:e000241.

56 Hamed S, Brenner B, Abassi Z, Aharon A, Daoud D, Roguin A: Hyperglycemia and oxidized-ldl exert a deleterious effect on endothelial progenitor cell migration in type 2 diabetes mellitus. Thromb Res 2010;126:166-174.

57 Chu L, Hao H, Luo M, Huang Y, Chen Z, Lu T, Zhao X, Verfaillie CM, Zweier JL, Liu Z: Ox-ldl modifies the behaviour of bone marrow stem cells and impairs their endothelial differentiation via inhibition of akt phosphorylation. J Cell Mol Med 2011;15:423-432.

58 Vasa M, Fichtlscherer S, Aicher A, Adler K, Urbich C, Martin H, Zeiher AM, Dimmeler S: Number and migratory activity of circulating endothelial progenitor cells inversely correlate with risk factors for coronary artery disease. Circ Res 2001;89:E1-7.

59 Javanmard SH, Gheisari Y, Soleimani M, Nematbakhsh M, Monajemi A: Effect of l-arginine on circulating endothelial progenitor cells in hypercholesterolemic rabbits. Int J Cardiol 2010;143:213-216.

60 Urbich C, Dimmeler S: Risk factors for coronary artery disease, circulating endothelial progenitor cells, and the role of hmg-coa reductase inhibitors. Kidney Int 2005;67:1672-1676.

61 Zhang F, Wang C, Wang H, Lu M, Li Y, Feng H, Lin J, Yuan Z, Wang X: Ox-ldl promotes migration and adhesion of bone marrow-derived mesenchymal stem cells via regulation of mcp-1 expression. Mediators Inflamm 2013;2013:691023.

62 Ji KT, Qian L, Nan JL, Xue YJ, Zhang SQ, Wang GQ Yin RP, Zhu YJ, Wang LP, Ma J, Liao LM, Tang JF: Oxldl induces dysfunction of endothelial progenitor cells via activation of nf-kappab. Biomed Res Int 2015;2015:175291.

63 Cui Y, Narasimhulu CA, Liu L, Zhang Q, Liu PZ, Li X, Xiao Y, Zhang J, Hao H, Xie X, He G, Cui L, Parthasarathy S, Liu Z: N-acetylcysteine inhibits in vivo oxidation of native low-density lipoprotein. Sci Rep 2015;5:16339.

64 Callaghan MJ, Ceradini DJ, Gurtner GC: Hyperglycemia-induced reactive oxygen species and impaired endothelial progenitor cell function. Antioxid Redox Signal 2005;7:1476-1482.

65 Tousoulis D, Papageorgiou N, Androulakis E, Siasos G, Latsios G, Tentolouris K, Stefanadis C: Diabetes mellitus-associated vascular impairment: Novel circulating biomarkers and therapeutic approaches. J Am Coll Cardiol 2013;62:667-676.

66 Lorenzen JM, Batkai S, Thum T: Regulation of cardiac and renal ischemia-reperfusion injury by micrornas. Free Radic Biol Med 2013;64:78-84.

67 Cui Y, Xie X, Jia F, He J, Li Z, Fu M, Hao H, Liu Y, Liu JZ, Cowan PJ, Zhu H, Sun Q, Liu Z: Ambient fine particulate matter induces apoptosis of endothelial progenitor cells through reactive oxygen species formation. Cell Physiol Biochem 2015;35:353-363. 


\section{Cellular Physiology Cell Physiol Biochem 2016;39:89-101 \begin{tabular}{l|l|l|}
\hline DOI: 10.1159/000445608 2016 & $\begin{array}{l}\text { C) 2016 The Author(s). Published by S. Karger AG, Basel } \\
\text { www.karger.com/cpb }\end{array}$
\end{tabular} \\ Zhang et al.: Probucol Protects EPC Against ox-LDL}

68 Lu C, Yu X, Zuo K, Zhang X, Cao C, Xu J, Wang S, Tang T, Ye M, Pei E, Uzan G, Zhi K, Li M: Tripterine treatment improves endothelial progenitor cell function via integrin-linked kinase. Cell Physiol Biochem 2015;37:1089-1103.

69 Guo W, Li Z, Xie X, Qin T, Wu Y, Li Z, Chai J, Yi F, Tan T, Zhu H, Wang S: Urinary trypsin inhibitor attenuates acute lung injury by improving endothelial progenitor cells functions. Cell Physiol Biochem 2015;36:10591068.

70 Ye M, Li D, Yang J, Xie J, Yu F, Ma Y, Zhu X, Zhao J, Lv Z: Microrna-130a targets map3k12 to modulate diabetic endothelial progenitor cell function. Cell Physiol Biochem 2015;36:712-726.

71 YanYun P, Wang S, Yang J, Chen B, Sun Z, Ye L, Zhu J, Wang X: Interruption of cd40 pathway improves efficacy of transplanted endothelial progenitor cells in monocrotaline induced pulmonary arterial hypertension. Cell Physiol Biochem 2015;36:683-696.

72 Chen Y, Zhao S, Huang B, Wang Y, Li Y, Waqar AB, Liu R, Bai L, Fan J, Liu E: Probucol and cilostazol exert a combinatorial anti-atherogenic effect in cholesterol-fed rabbits. Thromb Res 2013;132:565-571.

73 Carew TE, Schwenke DC, Steinberg D: Antiatherogenic effect of probucol unrelated to its hypocholesterolemic effect: Evidence that antioxidants in vivo can selectively inhibit low density lipoprotein degradation in macrophage-rich fatty streaks and slow the progression of atherosclerosis in the watanabe heritable hyperlipidemic rabbit. Proc Natl Acad Sci U S A 1987;84:7725-7729.

74 Anderson TJ, Meredith IT, Charbonneau F, Yeung AC, Frei B, Selwyn AP, Ganz P: Endothelium-dependent coronary vasomotion relates to the susceptibility of ldl to oxidation in humans. Circulation 1996;93:16471650.

75 Chen YH, Lin SJ, Chen YL, Liu PL, Chen JW: Anti-inflammatory effects of different drugs/agents with antioxidant property on endothelial expression of adhesion molecules. Cardiovasc Hematol Disord Drug Targets 2006;6:279-304.

76 Kyaw M, Yoshizumi M, Tsuchiya K, Izawa Y, Kanematsu Y, Tamaki T: Atheroprotective effects of antioxidants through inhibition of mitogen-activated protein kinases. Acta Pharmacol Sin 2004;25:977-985.

77 Anderson TJ, Meredith IT, Yeung AC, Frei B, Selwyn AP, Ganz P: The effect of cholesterol-lowering and antioxidant therapy on endothelium-dependent coronary vasomotion. N Engl J Med 1995;332:488-493.

78 Armengol Lopez S, Botham KM, Lawson C: The oxidative state of chylomicron remnants influences their modulation of human monocyte activation. Int J Vasc Med 2012;2012:942512.

79 Komai N, Morishita R, Yamada S, Oishi M, Iguchi S, Aoki M, Sasaki M, Sakurabayashi I, Higaki J, Ogihara T: Mitogenic activity of oxidized lipoprotein (a) on human vascular smooth muscle cells. Hypertension 2002;40:310-314.

80 Yasunari K, Kohno M, Kano H, Yokokawa K, Minami M, Yoshikawa J: Antioxidants improve impaired insulinmediated glucose uptake and prevent migration and proliferation of cultured rabbit coronary smooth muscle cells induced by high glucose. Circulation 1999;99:1370-1378.

81 Tanaka K, Hayashi K, Shingu T, Kuga Y, Nomura K, Kajiyama G: Probucol inhibits neointimal formation in carotid arteries of normocholesterolemic rabbits and the proliferation of cultured rabbit vascular smooth muscle cells. Cardiovasc Drugs Ther 1998;12:19-28.

82 Sheng L, Jiao B, Shao L, Bi S, Cheng C, Zhang J, Jiang Y: Probucol inhibits hydrogen peroxide to induce apoptosis of vascular smooth muscle cells. Mol Med Rep 2013;7:1185-1190.

83 Steinberg D, Parthasarathy S, Carew TE: In vivo inhibition of foam cell development by probucol in watanabe rabbits. Am J Cardiol 1988;62:6B-12B.

84 Ku G, Doherty NS, Wolos JA, Jackson RL: Inhibition by probucol of interleukin 1 secretion and its implication in atherosclerosis. Am J Cardiol 1988;62:77b-81b.

85 Bird DA, Tangirala RK, Fruebis J, Steinberg D, Witztum JL, Palinski W: Effect of probucol on ldl oxidation and atherosclerosis in ldl receptor-deficient mice. J Lipid Res 1998;39:1079-1090.

86 Cynshi O, Stocker R: Inhibition of lipoprotein lipid oxidation. Handb Exp Pharmacol 2005:563-590.

87 Rong H, Tan M: [effect of probucol on serum malondialdehyde and superoxide dismutase in patients with primary hypertension]. Zhong Nan Da Xue Xue Bao Yi Xue Ban 2012;37:458-462.

88 Inoue N, Ohara Y, Fukai T, Harrison DG, Nishida K: Probucol improves endothelial-dependent relaxation and decreases vascular superoxide production in cholesterol-fed rabbits. Am J Med Sci 1998;315:242-247.

89 Bonafe F, Guarnieri C, Muscari C: Nitric oxide regulates multiple functions and fate of adult progenitor and stem cells. J Physiol Biochem 2015;71:141-153. 